\title{
KAJIAN YURIDIS ATAS PELAKSANAAN PENGAWASAN TERHADAP JABATAN NOTARIS MENURUT UNDANG-UNDANG NOMOR 2 TAHUN 2014 DI KOTA TANGERANG
}

\author{
Oleh \\ Sri Jaya Lesmana*)
}

\begin{abstract}
Abstrak
Salah satu dasar hukum yang mengatur tentang pengawasan terhadap Notaris dalam menjalanakan tugas dan jabatnnya adalah Pasal 1 butir 6 Undang-undang Jabatan Notaris, yang berbunyi : Majelis Pengawas adalah suatu badan yang mempunyai kewenangan dan kewajiban untuk melaksanakan pembinaan dan pengawasan terhadap Notaris. Peran Majelis Pengawas Daerah yang sebelumnya melakukan pengawasan dan pembinaan, setelah Un-dang-Undang No. 2 Tahun 2014 ini diberlakukan menjadi terpisah yaitu oleh Majelis Pengawas Daerah dan Majelis Kehormatan Notaris. Pembinaan oleh Majelis Kehormatan Notaris diatur di dalam Pasal 66A, sedangkan pengawasan dilakukan oleh Majelis Pengawas Daerah yang diatur dalam Pasal 67. Pengawasan yang dilakukan oleh Pengawas selama ini terhadap Notaris dalam melaksanakan tugas dan jabatannya mempunyai dampak yang positif bagi pelaksanaan tugas Notaris. Alasannya bahwa pengawasan yang dilaksanakan oleh pengawas selama ini telah membawa dampak positif adalah bahwa pengawas telah melaksanakan tugasnya sesuai dengan peraturan perundangundangan yang berlaku, dan Notaris sendiri sudah lebih hati-hati dalam melaksanakan tugasnya terutama dalam pembuatan akta atau isi akta. Selain itu dampak positif lainnya adalah Notaris sudah melaksanakan tugasnya dengan baik dan lebih bersifat profesional. Namun sistem pengawasan yang dilakukan oleh Pengawas selama ini, berdasarkan hasil penelitian belum mencapai sasaran yang diharapkan.
\end{abstract}

\section{Kata Kunci : Jabatan Notaris, Majelis Pengawas Notaris}

\section{A.PENDAHULUAN}

Permasalahan hukum dapat terjadi dalam menjalankan profesi jabatan notaris, permasalahan hukum itu terjadi karena para pihak dalam akta tersebut baik sengaja ataupun tidak, menyampaikan dokumen pendukung maupun materi yang akan dituangkan dalam akta kepada seorang notaris tidak sesuai dengan keadaan sebenarnya/palsu/dipalsukan atau kurang

*) Penulis adalah Dosen Fakultas Hukum

Universitas Islam Syekh Yusuf Tangerang lengkap, dapat pula terjadi apabila para pihak atau salah satu pihak mengingkari dari akta yang telah mereka sepakati. Selain itu dapat juga terjadi karena kelalaian dan/atau kurang ketelitian/kecerobohan seorang notaris sehingga mengakibatkan akta yang dibuatnya mengalami permasalahan hukum. Permasalahan hukum itu muncul bisa pada saat itu, atau dapat muncul setelah beberapa tahun 
kemudian saat minuta akta telah disimpan dalam protokol notaris lain.

Dalam penyelesaian permasalahan hukum tersebut apabila tidak dapat diselesaikan secara kekeluargaan oleh para pihak, maka dapat diselesaikan secara hukum melalui proses peradilan. Terhadap permasalahan hukum yang terjadi dan memenuhi unsur perbuatan pidana maka penyidik dalam hal ini dilakukan oleh Kepolisian Republik Indonesia, sesuai domisili hukum yang dikehendaki para pihak atau wilayah kerja notaris yang bersangkutan. Penyidik berwenang melakukan pemanggilan kepada notaris yang bersangkutan, sebagai saksi maupun tersangka berkaitan dengan akta yang dibuatnya berdasarkan laporan kepolisian yang dibuat oleh para pihak dalam akta yang bermasalah tersebut.

Majelis pengawas adalah suatu badan yang mempunyai kewenangan dan kewajiban untuk melaksanakan pembinaan dan pengawasan terhadap Notaris. Pengawasan terhadap Notaris dimaksudkan agar Notaris dalam menjalankan tugas jabatannya wajib berdasarkan dan mengikuti peraturan perundang-undangan yang mengatur jabatan Notaris. Notaris dalam menjalankan tugas jabatannya wajib berpegang dan berdasarkan peraturan perundang-undangan yang mengatur jabatan Notaris secara melekat, artinya segala hal yang disebutkan dalam peraturan perundang-undangan yang mengatur jabatan Notaris wajib diikuti.

Tujuan dari pengawasan ialah bahwa Notaris dihadirkan untuk melayani kepentingan masyarakat yang membutuhkan alat bukti berupa akta otentik, sehingga tanpa adanya masyarakat yang membutuhkan Notaris maka Notaris tidak ada gunanya. Notaris diangkat oleh pemerintah, bukan untuk kepentingan Notaris itu semata, tetapi untuk kepentingan masyarakat umum. Terkait dengan akibat hukum di atas, sesuai dengan ketentuan dalam Pasal 67 - Pasal 81 Undang-Undang Nomor 2 Tahun 2014, telah diatur tentang pengawasan terhadap Notaris.

Berdasarkan uraian di atas, Penulis mengangkat permasalahan pengawasan Notaris di Kota Tangerang sebagai berikut :

1. Bagamana Pelaksanaan Pengawasan yang dilakukan oleh Majelis Pengawas Notaris Daerah Terhadap Jabatan Notaris Menurut UndangUndang Nomor 2 Tahun 2014 di Kota Tangerang ?

2. Apakah Kendala Pelaksanaan Pengawasan yang dilakukan oleh Majelis Pengawas Notaris Daerah Terhadap Jabatan Notaris Menurut Undang-Undang Nomor 2 Tahun 2014 di Kota Tangerang ?

3. Bagamana solusi pemecahan kendala Pelaksanaan Pengawasan yang dilakukan oleh Majelis Pengawas Notaris Daerah Terhadap Jabatan Notaris Menurut Undang-Undang Nomor 2 Tahun 2014 di Kota Tangerang ?

\section{B. PEMBAHASAN}

Pengertian Pengawasan menurut Sujamto, (2007:63), "Pengertian dasar dari pengawasan adalah segala usaha atau kegiatan untuk mengetahui dan menilai kenyataan yang sebenarnya tentang pelaksanaan tugas atau kegiatan, apakah sesuai dengan yang semestinya atau tidak". Menurut Sujamto, (2013:12) "Pengawasan adalah proses pengamatan dari pada pelaksanaan seluruh kegiatan organisasi untuk menjamin agar semua pekerjaan yang sedang dilaksanakan berjalan sesuai dengan rencana yang telah ditentukan sebelumnya". 
Pengawasan Notaris di Kota Tangerang didefinisikan sebagai proses pengamatan dari pada pelaksanaan seluruh kegiatan organisasi untuk menjamin agar semua pekerjaan yang sedang dilaksanakan berjalan sesuai dengan rencana yang telah ditentukan sebelumnya dengan indikator menurut Siagian, (2013:112), menyatakan bahwa sasaran lain yang perlu dicapai melalui pengawasan selain untuk tujuan efisiensi adalah:

1) Pelaksanaan tugas-tugas yang telah ditentukan berjalan sungguhsungguh sesuai dengan pola yang direncanakan

2) Struktur serta hierarki organisasi sesuai dengan pola yang ditentukan dalam rencana

3) Sistem dan prosedur kerja tidak menyimpang dari garis kebijakan yang telah tercermin dalam rencana

4) Tidak terdapat penyimpangan dan atau penyelewengan dalam penggunaan kekuasaan, kedudukan terutama keuntungan.

Apakah Notaris bekerja sesuai dengan Kewenangan Notaris yang di sebutkan dalam Pasal 15 dari ayat (1) sampai dengan ayat (3) Undangundang Jabatan Notaris, yang dapat dibagi menjadi (Habib Adjie, 2008:78)

1) Kewenangan Umum Notaris. Pasal 15 ayat (1) Undang-Undang Nomor 2 Tahun 2014

2) Kewenangan Khusus Notaris. Pasal 15 ayat (2) Undang-Undang Nomor 2 Tahun 2014

3) Kewenangan notaris yang akan ditentukan kemudian. Pasal 15 ayat (3) Undang-Undang Nomor 2 Tahun 2014

Mekanisme pengawasan yang dilakukan secara terus-menerus terhadap Notaris di dalam menjalankan tugas dan jabatannya sekarang dilaksanakan berdasarkan Undang-Undang No. 2
Tahun 2014 tentang perubahan atas Undang-Undang No. 30 Tahun 2004 tentang Jabatan Notaris, Pemeriksaan Majelis Pengawas. Dalam ketentuan Undang-Undang No. 2 Tahun 2014 tentang perubahan atas UndangUndang No. 30 Tahun 2004 tentang Jabatan Notaris, terdapat banyak perubahan mengenai Kewenangan Majelis Pengawas Daerah dalam melakukan pengawasan dan pembinaan terhadap Notaris.

Salah satu dasar hukum yang mengatur tentang pengawasan terhadap Notaris dalam menjalanakan tugas dan jabatnnya adalah Pasal 1 butir 6 Undang-undang Jabatan Notaris, yang berbunyi : Majelis Pengawas adalah suatu badan yang mempunyai kewenangan dan kewajiban untuk melaksanakan pembinaan dan pengawasan terhadap Notaris

Peran Majelis Pengawas Daerah yang sebelumnya melakukan pengawasan dan pembinaan, setelah Undang-Undang No. 2 Tahun 2014 ini diberlakukan menjadi terpisah yaitu oleh Majelis Pengawas Daerah dan Majelis Kehormatan Notaris. Pembinaan oleh Majelis Kehormatan Notaris diatur di dalam Pasal 66A, sedangkan pengawasan dilakukan oleh Majelis Pengawas Daerah yang diatur dalam Pasal 67. Sampai tulisan ini dibuat mengenai tugas dan fungsi dan tata cara pengangkatan dan pemberhentian, struktur organisasi, tata kerja dan anggaran majelis kehormatan Notaris berdasarkan Pasal 66A ayat (3) belum diatur dengan Peraturan Menteri

Majelis Pengawas Daerah tidak mempunyai kewenangan untuk menjatuhkan sanksi apapun. Meskipun Majelis Pengawas Daerah mempunyai wewenang untuk menerima laporan dari masyarakat dan dari Notaris lainnya dan menyelenggarakan sidang untuk memeriksa adanya dugaan pe- 
langgaran pelaksanaan jabatan Notaris, tapi tidak diberi kewenangan untuk menjatuhkan sanksi apapun. Majelis Pengawas Daerah hanya berwenang untuk melaporkan hasil sidang dan pemeriksaannya kepada Majelis Pengawas Wilayah dengan tembusan kepada pihak yang melaporkan, Notaris yang bersangkutan, Majelis Pengawas Pusat dan Organisasi Notaris (INI).

Pengawasan Majelis Pengawas Daerah terhadap Notaris meliputi jabatan Notaris dan perilaku Notaris. Pengawasan terhadap jabatan Notaris meliputi kewajiban dan kewenangannya sebagai Notaris berdasarkan Undang-Undang Jabatan Notaris, sedangkan pengawasan perilaku Notaris berdasarkan Kode Etik Notaris.

Setelah diberlakukannya UndangUndang Nomor 2 Tahun 2014 tentang perubahan atas Undang-Undang Nomor 30 Tahun 2004 tentang Jabatan Notaris, terdapat beberapa perubahan terhadap ketentuan yang mengatur Majelis Pengawas Daerah. Kewenangan dan Kewajiban Majelis Pengawas Daerah dalam hal pengawasan terhadap Notaris tidak mengalami perubahan. Perubahan terjadi dalam hal pembinaan terhadap Notaris. Pembinaan yang sebelumnya merupakan kewenangan Majelis Pengawas Daerah sekarang menjadi kewenangan Majelis Kehormatan Notaris

Kewenangan Majelis Pengawas Daerah sebagaimana dimaksud dalam Pasal 70 Undang-Undang Nomor 2 Tahun 2014, tentang Jabatan Notaris yang menyatakan bahwa :

a. Menyelenggarakan sidang untuk memeriksa adanya dugaan pelanggaran Kode Etik Notaris atau pelanggaran pelaksanaan Jabatan Notaris;

b. Melakukan pemeriksaan terhadap Protokol Notaris secara berkala 1 (satu) kali dalam 1 (satu) tahun atau setiap waktu yang dianggap perlu;

c. Memberikan izin cuti untuk waktu sampai dengan 6 (enam) bulan;

d. Menetapkan Notaris Pengganti dengan memperhatikan usul Notaris yang bersangkutan;

e. Menentukan tempat penyimpanan Protokol Notaris yang pada saat serah terima Protokol Notaris telah berumur 25 (duapuluh lima) tahun atau lebih;

f. Menunjuk Notaris yang akan bertindak sebagai pemegang sementara Protokol Notaris yang diangkat sebagai Pejabat Negara sebagaimana dimaksud dalam Pasal 11 ayat (4);

g. Menerima laporan dari masyarakat mengenai adanya dugaan pelanggaran Kode Etik Notaris atau pelanggaran ketentuan dalam Undang-Undang ini; dan

h. Membuat dan menyampaikan laporan sebagaimana dimaksud pada huruf $a$, huruf $b$, huruf $c$, huruf $d$, huruf e, huruf $f$ dan huruf $g$ kepada Majelis Pengawas Wilayah (MPW).

Pengawasan yang dilakukan pengawas selama ini bagi Notaris mempunyai manfaat yang besar, yaitu :

a. Notaris mampu untuk meningkatkan kemampuan profesionalismenya dalam menjalankan tugas dan jabatannya.

b. Notaris sedapat mungkin, memenuhi persyaratan-persyaratan yang ditentukan baginya sesuai dengan peraturan perundang-undangan yang ada.

c. Notaris mampu berperan untuk terciptanya suatu kepastian hukum melalui akta otentik yang dibuatnya demi kepentingan masyarakat. 
d. Notaris menyadari bahwa tugas yang dibebankan kepadanya adalah untuk kepentingan para pihak.

Berdasarkan hasil penelitian, pengawasan yang dilakukan oleh Pengawas selama ini terhadap Notaris dalam melaksanakan tugas dan jabatannya mempunyai dampak yang positif bagi pelaksanaan tugas Notaris. Alasannya bahwa pengawasan yang dilaksanakan oleh pengawas selama ini telah membawa dampak positif adalah bahwa pengawas telah melaksanakan tugasnya sesuai dengan peraturan perundang-undangan yang berlaku, dan Notaris sendiri sudah lebih hatihati dalam melaksanakan tugasnya terutama dalam pembuatan akta atau isi akta. Selain itu dampak positif lainnya adalah Notaris sudah melaksanakan tugasnya dengan baik dan lebih bersifat profesional. Namun sistem pengawasan yang dilakukan oleh Pengawas selama ini, berdasarkan hasil penelitian belum mencapai sasaran yang diharapkan.

Belum dicapainya sasaran yang diharapkan selama ini oleh responden mengemukakan alasan-alasannya sebagai berikut :

a. Karena banyaknya akta-akta yang dibuat oleh Notaris tidak sesuai atau belum sesuai dengan pengertian akta Notaris itu sebenarnya yaitu otentik

b. Pengawas selama ini belum profesional dalam memeriksa akta yang dibuat oleh Notaris.

c. Karena pengawas tidak memberikan informasi atau pengetahuan yang baru bagi Notaris khususnya dalam pelaksanaan tugas dan jabatan Notaris

Ketua Majelis Pengawas Daerah Notaris Kota Tangerang menguraikan beberapa upaya-upaya yang akan dilakukan oleh Majelis Pengawas
Daerah Notaris Kota Tangerang dalam rangka pembinaan dan pengawasan terhadap Notaris, pertama, adalah dengan menerapkan pengawasan yang bersifat preventif dan kuratif yakni melakukan pencegahan terhadap terjadinya pelanggaran jabatan Notaris dan melakukan pembinaan terhadap Notaris itu sendiri. Dalam penjelasannya, Ketua Majelis Pengawas Daerah Notaris Kota Tangerang menerangkan bahwa "pengawasan yang dilakukan oleh Majelis Pengawas saat ini khususnya Majelis Pengawas Daerah Notaris Kota Tangerang adalah pengawasan yang mengacu pada apa yang diatur dalam UUJN, Permen dan Kepmen. Dimana disebutkan dalam Permen pada Pasal 1 angka 5 bahwa pengawasan adalah kegiatan yang bersifat preventif dan kuratif termasuk kegiatan pembinan yang dilakukan oleh Majelis Pengawas terhadap Notaris.

Kedua, Majelis Pengawas Daerah Notaris Kota Tangerang juga akan melakukan sosialisasi-sosialisasi kepada pihak-pihak yang terkait dengan profesi Notaris antara lain unsur masyarakat, unsur Akademis, Kepolisian Republik Indonesia, dan terutama terhadap notaris-notaris yang berada di bawah kewenangannya.

Sosialisasi ini bertujuan agar pihak-pihak yang berhubungan dengan profesi Notaris dapat lebih memahami tentang keberadaan lembaga pengawas yang baru dibentuk, mengenai kewenangannya dalam menjaga penegakan Kode Etik Notaris. Selain itu sosialisasi ini juga bertujuan agar masyarakat sebagai pengguna jasa Notaris dapat lebih mengetahui hak dan kewajibannya sehingga apabila dikemudian hari terjadi pelanggaran yang dilakukan oleh Notaris, masyarakat dapat melaporkan pelanggaran tersebut kepada Majelis Pengawas Daerah 
Berkaitan dengan salah satu upaya yang dilakukan Majelis Pengawas Daerah Notaris Kota Tangerang dalam melaksanakan pengawasan terhadap Notaris, yakni melakukan pengawasan yang preventif dan kuratif, maka berdasarkan ketentuan-ketentuan di atas, penulis mencoba untuk mengidentifikasi kewenangan-kewenangan mana saja yang termasuk pengawasan yang bersifat preventif dan kewenangan-kewenangan mana saja yang termasuk pengawasan yang bersifat kuratif.

Kewenangan-kewenangan pengawasan yang bersifat preventif yang antara lain adalah hal-hal yang diatur Pasal 70 huruf b, c, d, e, f dan h UUJN, Pasal 13 ayat (2) huruf a, b, c, e dan f, dimana kewenangan-kewenangan tersebut bersifat administratif yang lebih mengatur tentang tata cara prosedural dan protokol kenotariatan. Sedangkan kewenangan-kewenangan pengawasan yang bersifat kuratif yang antara lain adalah hal-hal yang diatur Pasal 70 huruf a dan huruf g UUJN, Pasal 13 ayat (2) huruf $d$ yang mengatur tentang pengambilan tindakan terhadap dugaan-dugaan pelanggaran yang dilakukan oleh Notaris terhadap UUJN dan Kode Etik.

Keberadaan Majelis Pengawas Notaris khususnya Majelis Pengawas Daerah sebagai ujung tombak Majelis Pengawas, yang utama adalah untuk melakukan pengawasan terhadap penegakan Kode Etik Notaris dan pelaksanaan jabatan Notaris tersebut. Dalam melakukan pengawasan Majelis Pengawas Daerah harus tanggap dalam menangani pelanggaran yang dilakukan oleh Notaris. Selain itu Majelis Pengawas Daerah juga harus transparan dalam menangani setiap kasus pelanggaran yang terjadi, agar kewibawaan dan kapabilitasnya tetap terjaga dimata masyarakat. Keberadaan
Majelis Pengawasan Notaris jangan sampai menimbulkan kesan sebagai lembaga yang berpihak kepada Notaris. Majelis Pengawasan Notaris harus sungguh sungguh menjadi lembaga independen dalam melaksanakan tugas pembinan dan pengawasan kepada Notaris (Wawancara dengan Ketua Majelis Pengawas Daerah Notaris Kota Tangerang, Dilakukan di Tangerang, pada Tanggal, 25 April 2017)

\section{Kendala yang Timbul Dalam Melaksanakan Kewenangan Majelis Pengawas Daerah Notaris Serta Upaya - Upaya Untuk Mengatasinya.}

Instansi utama yang melakukan pengawasan dan pemeriksaan terhadap Notaris, yaitu Majelis Pengawas. Untuk kepentingan tertentu Majelis Pengawas membentuk Tim Pemeriksa dan Majelis Pemeriksa (Daerah, Wilayah, dan Pusat). Dengan demikian ada 3 (tiga) institusi dengan tugas melakukan pengawasan dan pemeriksaan terhadap Notaris dengan kewenangan masing-masing, yaitu :

a. Majelis Pengawas (Daerah, Wilayah dan Pusat); dengan kewenangan melakukan pengawasan terhadap pelaksanaan tugas jabatan Notaris dan Kode Etik Notaris dan tindak tanduk atau perilaku kehidupan Notaris.

b. Tim Pemeriksa, dengan kewenangan melakukan pemeriksaan terhadap Protokol Notaris secara berkala 1 (satu) kali dalam 1 (satu) tahun atau setiap waktu yang dianggap perlu.

c. Majelis Pemeriksa (Daerah, Wilayah dan Pusat), dengan kewenangan untuk memeriksa menerima laporan yang diterima dari masyarakat atau dari sesama Notaris.

Selanjutnya kendala yang ada adalah dari masing-masing Majelis 
Pengawas Daerah yang dibentuk yang terdiri dari 9 (sembilan) orang, melihat wilayah kerjanya di Kota Tangerang meliputi wilayah yang sangat luas dan jumlah Notaris di Kota Tangerang yang cukup banyak, yaitu 178 Notaris dapat menjadi kendala di kemudian hari, sehingga pelaksanaan ketentuan Pasal 70 Undang-Undang Jabatan Notaris tentang pemeriksaan Protokol Notaris secara berkala, yaitu 1 (satu) kali dalam 1 (satu) tahun atau setiap waktu yang dianggap perlu tidak dapat dilakukan, bahkan untuk wilayah Kota Tangerang baru dilaksanakan pemeriksaan pada tahun 2010 sejak UndangUndang Jabatan Notaris berlaku. (Dede Nurhayati, Wawancara, Sekretaris Majelis Pengawas Daerah Notaris di Kota Tangerang, (Tangerang, 25 April 2017).

\section{Upaya-Upaya Untuk Mengatasinya Kendala Dalam Melaksanakan Kewenangan Majelis Pengawas Daerah Notaris}

Untuk mencapai sebuah praktek pengawasan yang ideal, pada prinsipnya pengawasan sangat bergantung kepada bagaimana pengawasan itu dijalankan. Dengan kata lain, pelaksanaan pengawasan harus disesuaikan dengan kebutuhan dan tujuan yang hendak dicapai melalui pengawasan tersebut. Oleh karena itu, langkahlangkah yang diambil dalam melakukan pengawasan haruslah dipikirkan secara cermat dan teliti agar tepat sasaran.

Langkah-langkah pencegahan dan pembinaan yang dapat dilakukan oleh Majelis Pengawas Notaris Wilayah Banten idealnya harus dapat meningkatkan mutu dan kualitas pelayanan Notaris. Pencegahan dan pembinaan yang dilakukan harus didasari oleh kesadaran dan pemahaman yang tinggi atas nilai-nilai moral dan etika, untuk itu perlu diawali dengan menyamakan pandangan terlebih dahulu antara pihak-pihak terkait sehingga dapat mencapai suatu visi dan misi yang sama baik dalam pola pikir dan dalam tingkat pelaksanaannya, dengan demikian diharapkan tindakan pencegahan dan pembinaan yang kemudian akan dijalankan dapat mencapai tujuannya. Selanjutnya upaya yang dilakukan oleh Majelis Pengawas Pusat dalam menyikapi kendala akibat tidak adanya standar prosedur operasional pengawasan Notaris adalah dengan mengirimkan formulir-formulir seperti : formulir cuti dan formulir pemeriksaan 1 (satu) kali dalam setahun, namun hal tersebut sifatnya hanya kebijakan dari Majelis Pengawas Pusat saja yang tidak diatur secara tegas dalam peraturan perundang-undangan yang ada.

\section{PENUTUP}

Pengawasan yang dilaksanakan oleh pengawas selama ini telah membawa dampak positif adalah bahwa pengawas telah melaksanakan tugasnya sesuai dengan UndangUndang Jabatan Notaris Nomor 2 Tahun 2014 tentang Jabatan Notaris.

Kendala yang timbul dalam pelaksanaan pengawasan Notaris oleh Majelis Pengawas Notaris Daerah adalah wilayah kerja yang sangat luas di Kota Tangerang dan jumlah Notaris yang cukup banyak di Kota Tangerang, sehingga mempersulit pembagian tugas pengawasan yang diemban oleh masing-masing anggota, anggaran dari Pemerintah sangat sedikit padahal tugas Majelis Pengawas membutuhkan dana yang besar dari pemerintah, kurangnya Sosialisasi Undang-Undang Jabatan Notaris Nomor 2 Tahun 2014 tentang Jabatan Notaris kepada 
masyarakat sehingga masyarakat tidak mengetahui undang-undang tersebut yang berdampak semakin seringnya Notaris melakukan kecurangan, serta apabila Majelis Pengawas Daerah tidak memberikan persetujuan kepada pihak Kepolisian, Kejaksaan dan Hakim untuk memeriksa Notaris dapat mengakibatkan terjadinya kesalah pahaman dari pihak Kepolisian, Kejaksaan dan Hakim kepada Majelis Pengawas Daerah. Sedangkan upaya-upaya yang dilakukan adalah dengan melakukan kunjungan ke tiap-tiap Kantor Notaris di wilayah Kota Tangerang untuk melakukan pemeriksaan Protokol Notaris secara berkala, yaitu 1 (satu) kali dalam 1 (satu) tahun atau setiap waktu yang dianggap perlu tetapi pengawasan terhadap tugas jabatan Notaris tetap dilakukan setiap saat. Berdasarkan hasil wawancara dengan Ketua Majelis Pengawas Notaris Daerah Kota Tangerang, pengawasan yang dilakukan oleh Majelis Pengawas saat ini khususnya Majelis Pengawas Notaris Daerah Kota Tangerang, pengawasan yang dilakukan sangat terbatas pada apa yang diatur dalam Undang-Undang Jabatan Notaris, Peraturan Menteri dan Keputusan Menteri, dimana disebutkan bahwa pelaksanaan tersebut bersifat preventif dan kuratif, yang artinya bahwa pengawasan dijalankan dengan cara melakukan pencegahan dan pembinaan.

Solusi kendala pengawasan yang dilakukan oleh Majelis Pengawas saat ini khususnya Majelis Pengawas Notaris Daerah Kota Tangerang, pengawasan yang dilakukan sangat terbatas pada apa yang diatur dalam Undang-Undang Jabatan Notaris Nomor 2 Tahun 2014 tentang Jabatan Notaris, Sedangkan upaya yang dilakukan adalah dengan melakukan kunjungan ke tiap Kantor Notaris di Kota Tangerang secara berkala.

\section{DAFTAR PUSTAKA}

Habib Adjie, 2008, Hukum Notaris Indonesia, Tafsir Tematik Terhadap UU No. 30 Tahun 2004 Tentang Jabatan Notaris, Refika Aditama, Bandung

Sigian, 2013, "Filsafat Administrasi", Bumi Aksara, Jakarta

Sujamto, 2013, Beberapa Pengertian di Bidang Pengawasan, Ghalia Indonesia, Jakarta.

Undang-Undang Jabatan Notaris

Nomor 2 Tahun 2014 tentang Jabatan Notaris 